University of Nebraska - Lincoln

DigitalCommons@University of Nebraska - Lincoln

\title{
Femur-Marrow Fat of White-Tailed Deer Fawns Killed by Wolves
}

L. David Mech

USGS Northern Prairie Wildlife Research Center, david_mech@usgs.gov

Follow this and additional works at: https://digitalcommons.unl.edu/usgsnpwrc

Part of the Other International and Area Studies Commons

Mech, L. David, "Femur-Marrow Fat of White-Tailed Deer Fawns Killed by Wolves" (2007). USGS Northern Prairie Wildlife Research Center. 101.

https://digitalcommons.unl.edu/usgsnpwrc/101

This Article is brought to you for free and open access by the US Geological Survey at DigitalCommons@University of Nebraska - Lincoln. It has been accepted for inclusion in USGS Northern Prairie Wildlife Research Center by an authorized administrator of DigitalCommons@University of Nebraska - Lincoln. 


\title{
Femur-Marrow Fat of White-Tailed Deer Fawns Killed by Wolves
}

\author{
L. D. MECH, ${ }^{\mathbf{1}}$ Biological Resources Discipline, United States Geological Survey, Northern Prairie Wildife Research Center, 871137 th Street S.E., \\ Jamestown, ND 58401-7317, USA
}

\begin{abstract}
I present marrow fat (MF) data from a large sample of white-tailed deer fawns killed by wolves and a sample of fawns that died by accident in a single area, and I use these data to explore the extent that poor nutritional condition may have predisposed fawns to wolf predation. Percent MF of 110 5-10-month-old white-tailed deer (Odocoileus virginianus) fawns killed by wolves (Canis lupus) from November through April 1984-2002 in northeastern Minnesota, USA, was lower than MF for 23 fawns killed by accidents in the same area and period. The MF of both male and female wolf-killed fawns decreased over winter. The MF of male fawns decreased as a snow-depth index increased, but MF of females showed little relationship to the snow-depth index and was higher than that of males. Poor nutritional condition is one factor that predisposes deer fawns to wolf predation during winter and spring. This information expands our knowledge of wolf-prey relations by documenting that, even with younger prey animals that might be thought vulnerable because of youth alone, poor nutritional condition also is an important factor predisposing them to wolf predation. (JOURNAL OF WILDLIFE MANAGEMENT 71(3):920-923; 2007)
\end{abstract}

DOI: $10.2193 / 2006-153$

KEY WORDS Canis lupus, marrow fat, mortality, nutritional condition, Odocoileus virginianus, predation, white-tailed deer, wolf.

A substantial proportion of ungulate prey killed by wolves (Canis lupus) is comprised of young-of-the-year (summarized by Mech and Peterson 2003). Of adult ungulates that wolves kill, a high proportion is old, debilitated, or otherwise compromised (Mech 1970, Mech et al. 1998, Mech and Peterson 2003). These facts prompt the question: to what extent are young-of-the-year prey that are killed taken merely because they are small, less experienced, and otherwise vulnerable due to their age? Similarly, to what extent do young-of-the-year fall prey to wolves because of other vulnerabilities such as poor nutritional condition (Seal et al. 1978, Kunkel and Mech 1994)? Data on the percentage of fat in the femur marrow (MF) of whitetailed deer (Odocoileus virginianus) fawns killed in winter and spring could yield insights into these questions.

However, the only MF data available from free-ranging, white-tailed deer fawns in wolf range are from Quebec, Canada (Goudreault 1977), from a few fawns from Ontario, Canada (Kolenosky 1972) where MF was estimated rather than measured, and from northwestern Minnesota, USA (Fritts and Mech 1981). The Quebec data are most extensive because they cover several study areas but the samples per area are small. I present MF data from a large sample of white-tailed deer fawns killed by wolves and a sample of fawns that died by accidents in a single study area, and I use these data to explore the extent that poor nutritional condition may have predisposed fawns to wolf predation. Because this is the first large sample of whitetailed deer fawn MF data studied from a single area, I also examined relationships between MF and both month and a snow-depth index to determine the extent to which these factors may influence MF.

\footnotetext{
${ }^{1}$ E-mail: david_mech@usgs.gov

2 Mailing address: The Raptor Center, 1920 Fitch Avenue, University of Minnesota, St. Paul, MN 55108, USA
}

\section{STUDY AREA}

The study area encompassed some $2,060 \mathrm{~km}^{2}$ immediately east of Ely in the east-central Superior National Forest $\left(48^{\circ} \mathrm{N}, 92^{\circ} \mathrm{W}\right)$ of Minnesota. The topography varied from large stretches of swamps to rocky ridges, with elevations ranging from $325 \mathrm{~m}$ to $700 \mathrm{~m}$ above sea level. Winter temperatures $<-35^{\circ} \mathrm{C}$ were not unusual, and snow depths (usually from about mid-Nov through mid-Apr) generally ranged from $50 \mathrm{~cm}$ to $75 \mathrm{~cm}$ on the level. Temperatures in summer rarely exceeded $+35^{\circ} \mathrm{C}$.

Conifers predominated in the forest overstory, with the following species present: jack pine (Pinus banksiana), white pine (Pinus strobus), red pine (Pinus resinosa), black spruce (Picea mariana), white spruce (Picea glauca), balsam fir (Abies balsamea), white cedar (Thuja occidentalis), and tamarack (Latrix laricina). However, as a result of extensive cutting and fires, much of the conifer cover was interspersed with large stands of white birch (Betula papyrifera) and aspen (Populus tremuloides). Detailed descriptions of the forest vegetation were presented by Ohmann and Ream (1969).

The study area was located near the northern limit of white-tailed deer distribution. Deer inhabited the southwestern half of the study area year-round, and moose (Alces alces) inhabited the entire study area but at a higher density in the northeastern half (Peek et al. 1976). In spring, most of the deer migrated northeastward, returning later in the autumn (Hoskinson and Mech 1976, Nelson and Mech 1981). Beavers (Castor canadensis) were available throughout the study area, but generally only during April-November because of ice during the rest of the year. Wolves consumed all 3 prey species (Frenzel 1974), but in the southwestern half of the area, the main prey were deer.

In August 1974, wolves in Minnesota were afforded protection under the Endangered Species Act of 1973, and they remain legally protected. However, in accessible parts 


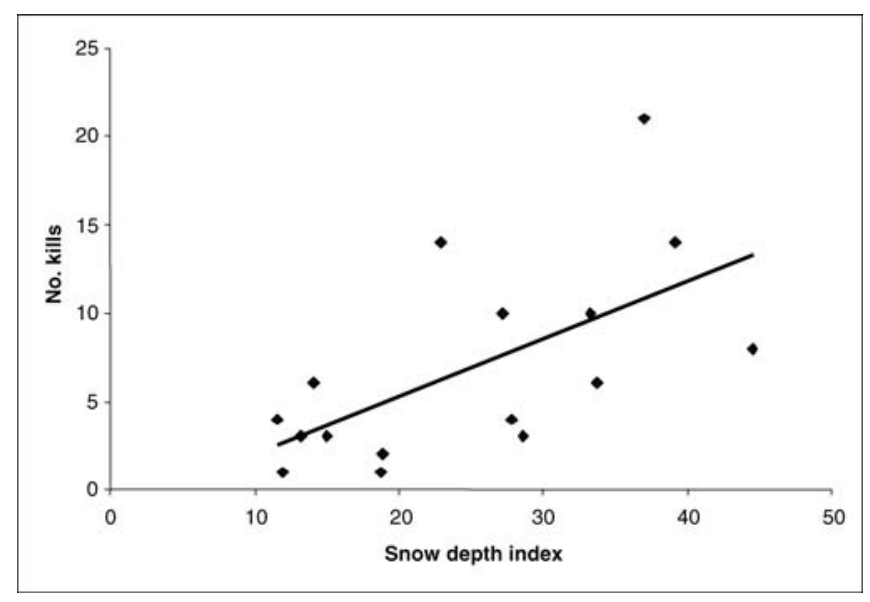

Figure 1. Relationship between number of wolf-killed fawns (whose marrow fat was measured) and snow-depth index in northeastern Minnesota, USA, from November through April 1984-2002.

of the study area, light to moderate illegal killing of wolves continued, primarily in autumn and winter (Mech 1977; L. D. Mech, United States Geological Survey, unpublished data). In most of the study area, only antlered deer could legally be harvested during this study, but east, south, and west of the area, limited numbers of antlerless deer could be harvested as well.

\section{METHODS}

My assistants and I live-trapped wolves throughout the study area (Mech 1974), radiotagged, and aerially radiotracked them at least once per week. During winter and spring, we routinely observed them and prey that they killed. Generally, we flew more frequently in February and March, and our observations in April were often hindered by lack of snow. Thus, we obtained most of our data during February and March, although I analyzed data collected from November to April, 1984-2002. We physically examined wolf-killed deer (characterized by bloody snow and presence of wolves or wolf tracks). We determined whether a kill was of an adult or fawn from the skull or jaw when present or from size of other remains. We determined sex by presence or absence of antlers or pedicels, and we collected any femurs found. We also collected femurs from all road-killed fawns we found and from fawns that perished subsequent to capture in our live-trapping and radiotagging studies (Nelson and Mech 1984, 1999) in the same area during the same period to represent a general-population sample. The bones were fresh, intact, and frozen when we collected them, and we removed the marrow from the center of the bone 1-4 days after the fawn had been killed and on the same day we collected the bone. We immediately oven-dried and weighed the marrow before and after drying to determine percent fat content (Neiland 1970). We measured snow depth weekly at 6 locations in open-canopy sites between trees in broadleaf-conifer forests, and defined a snow-depth index as the sum of weekly depth in feet from November through April.

I used linear regression to examine relationships between
Table 1. Percent femur-marrow fat in samples of 5-10-month-old whitetailed deer fawns from the central Superior National Forest, Minnesota, USA, November-April, 1984-2002.

\begin{tabular}{|c|c|c|c|c|c|c|c|c|c|}
\hline \multirow[b]{2}{*}{ Sex } & \multicolumn{4}{|c|}{ General sample } & \multicolumn{4}{|c|}{ Wolf-killed } & \multirow[b]{2}{*}{$P^{\mathrm{a}}$} \\
\hline & $N$ & $\bar{x}$ & SE & Range & $N$ & $\bar{x}$ & SE & Range & \\
\hline $\mathrm{F}$ & 11 & 66 & 6.5 & $21-96$ & 29 & 58 & 4.8 & 11-97 & $0.19^{\mathrm{b}}$ \\
\hline M & 10 & 67 & 6.0 & 44-96 & 30 & 48 & 5.1 & $3-98$ & 0.02 \\
\hline Unknown & 2 & 52 & $21-83$ & $21-83$ & 51 & 65 & 3.2 & $8-96$ & 0.44 \\
\hline
\end{tabular}

${ }^{a}$ Probability of no difference between the $\bar{x}$ of the general sample and $\bar{x}$ of the wolf-killed sample.

b Probability of no difference in means of $\mathrm{M}$ and $\mathrm{F}$ wolf-killed samples: $P$ $=0.06$.

MF and other variables and fitted linear and second-order polynomial models. I used Kolmogorov-Smirnov tests to determine whether the distribution of my samples were similar enough for valid comparisons, and 2-sample $t$-tests to compare means. I used chi-squared tests to distinguish differences between the general-population sample and the wolf-killed sample.

\section{RESULTS}

We found 173 wolf-killed, white-tailed deer fawns during the study, and 110 of those killed from November through April possessed femur-marrow fat (MF) that we could measure. Of those, 30 were males, 29 females, and 51 were of unknown sex. The number of fawns we found killed by wolves increased as the snow-depth index increased $\left(r^{2}=\right.$ $0.38, P=0.01, \mathrm{y}=0.33 \mathrm{x}-1.3269, n=110$; Fig. 1$)$. Data also were available on MF from femurs of 10 males, 11 females, and 2 fawns of unknown sex from road kills and capture-related deaths. There were no significant differences in the yearly (2-tailed Kolmogorov-Smirnov $D=0.16, P=$ 0.86 ) or monthly (2-tailed Kolmogorov-Smirnov $D=0.08$, $P=1.00)$ distributions of our general fawn population sample and our wolf-killed sample. Thus, differences found between the 2 samples probably were not due to differences in years or months of collection.

The MF for fawns from the general population sample varied from $21 \%$ to $96 \%$ and MF for fawns from the wolfkilled sample varied from $3 \%$ to $98 \%$ (Table 1 ). The MF of both males and females from the general sample and from the wolf-killed sample decreased from November through April (Table 2). The MF of male and female fawns from the general population was not related to the snow-depth index, but the MF of the wolf-killed sample and of its male subsample decreased (Fig. 2) as the snow-depth index increased (Table 2). Wolf-killed female fawns possessed $21 \%$ higher $(P=0.06) \mathrm{MF}$ than males (Table 1$)$, and the MF of both males and females decreased as winter progressed (Fig. 3). The mean percent MF of the wolfkilled fawns was $12 \%$ lower than that of the general sample for females and $28 \%$ lower for males; the difference for females was nonsignificant $(P=0.19)$, whereas it was significant for males $(P=0.02$; Table 1$)$. 
Table 2. Relationship between percent femur marrow fat of 5-10-month-old white-tailed deer fawns, month, and snow-depth index in the central Superior National Forest of Minnesota, USA, 1984-2002.

\begin{tabular}{|c|c|c|c|c|c|}
\hline$N$ & Sex & Independent variable & $r^{2}$ & $P$ & Equation $^{a}$ \\
\hline \multicolumn{6}{|c|}{ General population $^{\mathrm{b}}$} \\
\hline 23 & $\mathrm{M}, \mathrm{F}, ?$ & Month & 0.60 & 0.0001 & \multirow[t]{2}{*}{$y=-2.4426 x^{2}+5.5481+85.553$} \\
\hline 23 & $\mathrm{M}, \mathrm{F}, ?$ & Snow index & 0.04 & 0.34 & \\
\hline 10 & $\mathrm{M}$ & Month & 0.76 & 0.007 & \multirow[t]{2}{*}{$y=2.9871 x^{2}-42.214 x+187.01$} \\
\hline 10 & M & Snow index & 0.03 & 0.65 & \\
\hline 11 & $\mathrm{~F}$ & Month & 0.58 & 0.03 & \multirow[t]{2}{*}{$\mathrm{y}=-2.4986 \mathrm{x}^{2}+7.3529 \mathrm{x}+80.629$} \\
\hline 11 & $\mathrm{~F}$ & Snow index & $<0.01$ & & \\
\hline \multicolumn{6}{|c|}{ Wolf-killed } \\
\hline 110 & $M, F, ?$ & Month & 0.47 & 0.0001 & \multirow{6}{*}{$\begin{array}{l}y=-2787 x^{2}+8.0886 x+73.706 \\
y=-1.0549 x+90.245 \\
y=-13.822 x+105.12 \\
y=-0.073 x^{2}+2.2653 x+52.427 \\
y=-2.7026 x^{2}+8.1298 x+72.651\end{array}$} \\
\hline 110 & $\mathrm{M}, \mathrm{F}$, ? & Snow index & 0.15 & 0.0001 & \\
\hline 30 & $M$ & Month & 0.47 & 0.0001 & \\
\hline 30 & M & Snow index & 0.39 & 0.0001 & \\
\hline 29 & $\mathrm{~F}$ & Month & 0.46 & 0.0003 & \\
\hline 29 & $\mathrm{~F}$ & Snow index & 0.04 & 0.29 & \\
\hline
\end{tabular}

${ }^{a}$ In equations where $\mathrm{x}=$ month, $\mathrm{Nov}=1, \mathrm{Dec}=2$, etc.; where $\mathrm{x}=$ snow index, values are $0-50$, as in Fig. 1 .

${ }^{\mathrm{b}}$ Road-kills and capture-related deaths.

\section{DISCUSSION}

The MF of fawns in general decreased over winter and into spring as expected, and by March and April, most fawns possessed relatively low MF. The mean MF of my general sample $(67 \%)$ was not significantly $(P=0.12)$ lower than that of Watkins et al. (1991) for 16 northern Illinois, USA, fawns $(75 \%)$ based on data estimated from a graph. Contrary to expectation, the MF content of my general fawn sample did not decrease significantly as snow depth increased, perhaps because the sample was too small. The MF of wolf-killed male fawns did decrease significantly with increasing snow depth. Interestingly, MF of wolf-killed female fawns showed little relationship to the snow-depth index. This finding may have been related to the generally higher MF content of females, and perhaps to the lower mass of females (Petraborg and Burcalow 1965) that may make them more resistant to extreme fat loss (Verme and

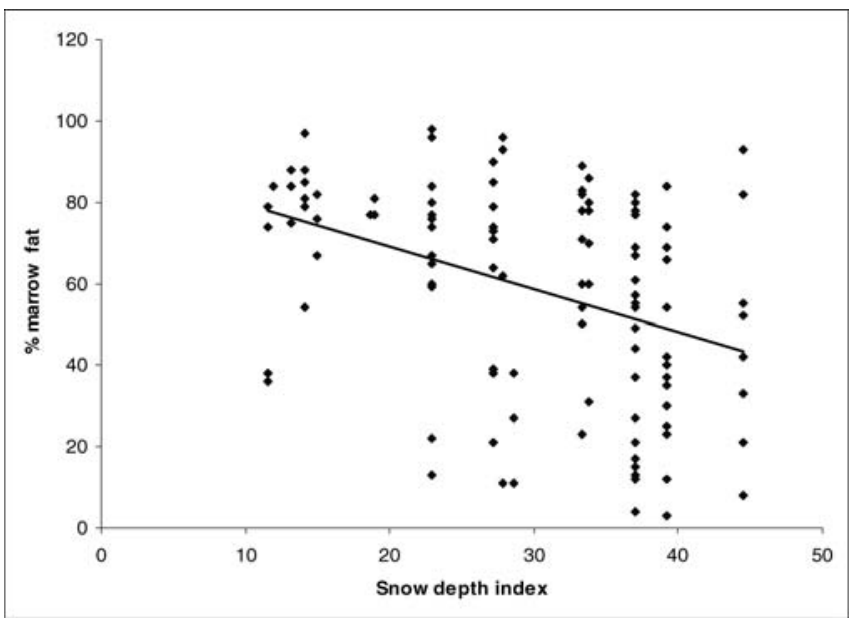

Figure 2. Relationship between femur marrow fat of white-tailed deer fawns killed by wolves and snow-depth index in northeastern Minnesota, USA, from November through April 1984-2002.
Ozoga 1980). My findings agree with those of Goudreault (1977:42) who concluded that "winter affects male fawns more severely than their female counterparts."

At least some fawns with low MF were available throughout each winter, but more were available during winters with greater snow depth and later in the winter. Thus, wolves killed more fawns when snow-depth was greater and as winter progressed. On average, the fawns that wolves killed possessed lower marrow fat than did the general population of fawns. This finding suggests low nutritional condition as a factor that predisposes 5-11month-old deer fawns to wolf predation. Seal et al. (1978) also found that wolf-killed 8-11-month-old deer fawns in this same area had lower nonesterified fatty acids in their blood upon capture than did survivors. The mean MF of wolf-killed fawns in my sample $(53 \%)$ was lower than the

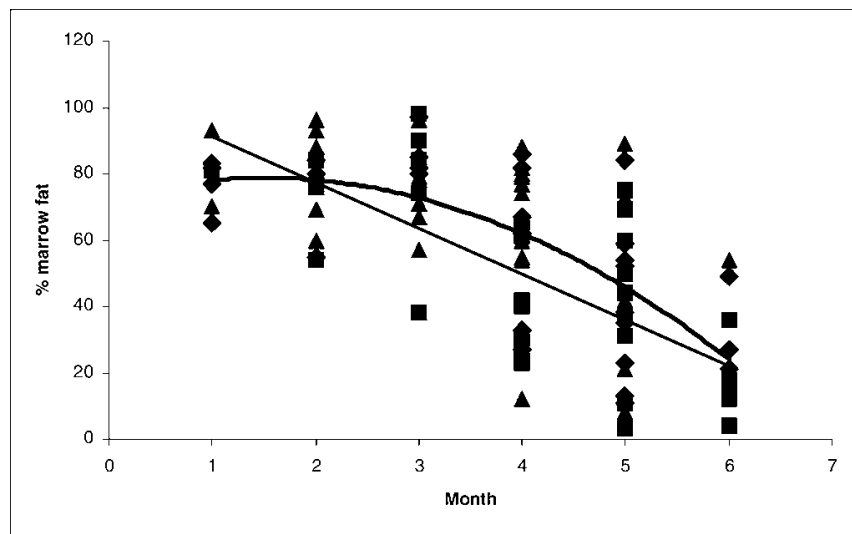

Figure 3. Relationship between femur marrow fat of white-tailed deer fawns killed by wolves in northeastern Minnesota, USA, from November (month 1) through April (month 6), 1984-2002. Triangles represent females; squares, males; and diamonds, sex unknown. Heavy curve represents females; light line, males. 
$82 \% \mathrm{MF}$ of wolf-killed fawns in northwestern Minnesota (Fritts and Mech 1981).

Fawns with low MF were killed by wolves during other studies (Mech and Frenzel 1971, Kolenosky 1972, Goudreault 1977, Fritts and Mech 1981). However, no controls were available for comparison in most of those studies, and most of the fawn-MF information provided by those studies was cursory. In Ontario, Kolenosky (1972) showed that fawns killed by wolves in March possessed 10-60\% MF while those in January-February had 90\% MF; however, percent MF was estimated, not measured, and the sample was small $(n=7)$. Goundreault conducted the most comprehensive study of winter fawn MF, but his sample of 52 wolf-killed fawns was spread over 8 study areas. He concluded that, in 2 zones with the largest fawn sample, deer killed by predation had a lower fat content than those that died accidentally (Goudreault 1977), although his data for fawns appeared equivocal (Goudreault 1977).

The results of this study demonstrate that 5-10-monthold fawns in my study area may be predisposed to wolf predation by low nutritional condition and not just because they are younger and less experienced than adults. This conclusion is in accord with the generalization that adult prey killed by wolves tend to have nutritional or other conditions that predispose them to wolf predation (summarized by Mech and Peterson 2003), and with the findings that deer fawns in Minnesota succumbing to predation from May through October were poorer nutrionally than survivors (Kunkel and Mech 1994, Carstensen-Powell 2004). My results increase understanding of wolf-prey interactions and, along with the studies cited above, also shed light on the role of predation on young animals in natural selection (White et al. 1972).

\section{MANAGEMENT IMPLICATIONS}

In northern areas where both wolves and hunters kill whitetailed deer, and where winters are often severe, harvesting of antlerless deer, including fawns, in autumn would increase human yield of deer that would otherwise be killed by wolves the following winter or spring. This approach to managing ungulates could soon become increasingly important in more areas as wolf recovery progresses in the northern United States.

\section{ACKNOWLEDGMENTS}

The Biological Resources Discipline of the United States Geological Survey, the United States Department of Agriculture North Central Research Station, and the Superior National Forest funded this study. I thank M. E. Nelson and several volunteers for assisting in collecting these data, and M. E. Nelson, S. Barber-Meyer, M. Carstensen-Powell, and 2 anonymous reviewers for offering helpful suggestions for improving the manuscript.

\section{LITERATURE CITED}

Carstensen-Powell, M. 2004. Winter severity, deer nutrition and fawning characteristics. Dissertation, University of Minnesota, St. Paul, USA.

Frenzel, L. D. 1974. Occurrence of moose in food of wolves as revealed by scat analyses: a review of North American studies. Le Naturaliste Canadien 101:467-479.

Fritts, S. H., and L. D. Mech. 1981. Dynamics, movements, and feeding ecology of a newly protected wolf population in northwestern Minnesota. Wildlife Monographs 80 .

Goudreault, F. 1977. Physiological response of deer to winter stress in Quebec as determined by femur fat content. Pages 37-55 in F. Potvin and J. Huot, editors. Northeastern Deer Study Group Meeting. Ministered du Loisir, de la Chasse et de la Peche, du Quebec, Canada.

Hoskinson, R. L., and L. D. Mech. 1976. White-tailed deer migration and its role in wolf predation. Journal of Wildlife Management 40:429-441.

Kolenosky, G. B. 1972. Wolf predation on wintering deer in east-central Ontario. Journal of Wildlife Management 36:357-369.

Kunkel, K. E., and L. D. Mech. 1994. Wolf and bear predation on whitetailed deer fawns. Canadian Journal of Zoology 72:1557-1565.

Mech, L. D. 1970. The wolf: the ecology and behavior of an endangered species. Doubleday, New York, New York, USA.

Mech, L. D. 1974. Current techniques in the study of elusive wilderness carnivores. Pages 315-322 in Proceedings of the 11th International Congress of Game Biologists, 3-7 September 1973, Stockholm, Sweden.

Mech, L. D. 1977. Productivity, mortality and population trends of wolves in northeastern Minnesota. Journal of Mammalogy 58:559-574.

Mech, L. D., L. G. Adams, T. J. Meier, J. W. Burch, and B. W. Dale. 1998. The wolves of Denali. University of Minnesota Press, Minneapolis, USA.

Mech, L. D., and L. D. Frenzel, Jr. 1971. Ecological studies of the timber wolf in northeastern Minnesota. U.S. Department of Agriculture Forest Service Research Paper NC-52. North Central Forest Experiment Station, St. Paul, Minnesota, USA.

Mech, L. D., and R. O. Peterson. 2003. Wolf-prey relations. Pages 131157 in L. D. Mech and L. Boitani, editors. Wolves: behavior, ecology, and conservation. University of Chicago Press, Illinois, USA.

Neiland, K. A. 1970. Weight of dried marrow fat as indicators of fat in caribou femurs. Journal of Wildlife Management 34:904-907.

Nelson, M. E., and L. D. Mech. 1981. Deer social organization and wolf depredation in northeastern Minnesota. Wildlife Monographs 77.

Nelson, M. E., and L. D. Mech. 1984. Home range formation and dispersal of deer in northeastern Minnesota. Journal of Mammalogy 65:567-575.

Nelson, M. E., and L. D. Mech. 1999. Twenty-year home range dynamics of a white-tailed deer matriline. Canadian Journal of Zoology 77:11281135 .

Ohmann, L. F., and R. R. Ream. 1969. Vegetation studies in the BWCAa brief paper on plant communities. Naturalist 20(1):20-29.

Peek, J. M., D. L. Urich, and R. J. Mackie. 1976. Moose habitat selection and relationships to forest management in northeastern Minnesota. Wildlife Monographs 48.

Petraborg, W. H., and D. W. Burcalow. 1965. The white-tailed deer in Minnesota. Pages 11-48 in J. B. Moyle, editor. Big game of Minnesota. Minnesota Department of Conservation Technical Bulletin 9, St. Paul, USA.

Seal, U. S., M. E. Nelson, L. D. Mech, and R. L. Hoskinson. 1978. Metabolic indicators of habitat differences in four Minnesota deer populations. Journal of Wildlife Management 42:746-754.

Verme, L. J., and J. J. Ozoga. 1980. Effect of diet on growth and lipogenesis in deer fawns. Journal of Wildlife Management 44:315-324.

Watkins, B. E., J. H. Witham, D. E. Ullrey, D. J. Watkins, and J. M. Jones. 1991. Body composition and condition evaluation of white-tailed deer fawns. Journal of Wildlife Management 55:39-51.

White, M., F. F. Knowlton, and W. C. Glazener. 1972. Effects of damnewborn fawn behavior on capture and mortality. Journal of Wildlife Management 36:897-906.

Associate Editor: McCorquodale. 